\title{
PROTECTION OF OPIATE RECEPTORS IN NG108-15 AGAINST MODIFICATION BY $N$-ETHYLMALEIMIDE
}

\author{
DEBRA MULLIKIN-KILPATRICK, ${ }^{1}$ NANCY E. LARSEN, ${ }^{2}$ AND ARTHUR J. BLUME
}

Department of Physiological Chemistry and Pharmacology, Roche Institute of Molecular Biology, Nutley, New Jersey 07110

Received March 16, 1982; Revised August 6, 1982; Accepted August 19, 1982

\begin{abstract}
Two different $-\mathrm{SH}$ groups associated with the opiate receptors of the mouse neuroblastoma $\times$ rat glioma hybrid NG108-15 have been identified. Modification of these by $N$-ethylmaleimide (NEM) (presumed to be via alkylation) or by para-chloromercuribenzoic acid (presumed to be via formation of mercury adducts) decreases the binding of both opiate agonists and antagonists to these receptors. Agonist binding is more sensitive than antagonist binding to modification by NEM. Losses in antagonist binding are accounted for totally by decreases in the number of binding sites; there are no corresponding losses in antagonist affinity. Losses of antagonist binding exhibit a pseudo-first order rate constant; the modification of only one such group completely destroys the binding sile. Both agonists and antagonists protect against modification of this group by NEM. Sodium and lithium, but not GTP, also protect this group, indicating that the action of these monovalent cations is directly on the receptor moiety. Losses in agonist binding stem not only from decreases in receptor number but also from selective losses in affinity. This - SH group appears to be different from the one at the binding site as sodium, GTP, and antagonist ligands do not protect against losses in agonist affinity. Agonist high affinity also is lost in a pseudo-first order fashion indicating that an alteration of only one $-\mathrm{SH}$ group per receptor complex is sufficient to produce this effect. The possible roles of two sulfhydryls in opiate receptor function are discussed.
\end{abstract}

The presence of opiate receptors in cultured cells was first demonstrated in the mouse neuroblastoma $\times$ rat glioma hybrid NG108-15 (Klee and Nirenberg, 1974) and has since been reported in other mouse neuroblastoma clones as well (Chang et al., 1978). In all of these lines, the receptors have been likened to those found in the brain and the mouse vas deferens and have been subclassified as "delta" (Lord et al., 1977; Chang and Cuatrecasas, 1979). In NG108-15, opiate agonists (both alkaloids and peptides) regulate the activity of at least two enzymes located within the cell's plasma membrane: adenylate cyclase (Sharma et al., 1975) and a GTPase (Koski and Klee, 1981). Sodium and guanine nucleotides are required, in vitro, for these two opiate sequelas (Blume et al., 1979a; Koski and Klee, 1981) and both agents modify the binding of opiate agonists to their receptors (Blume, 1978; Blume et al., 1979b).

Two different $N$-ethylmaleimide (NEM)-sensitive sites (presumed - SH groups) have been described recently by Larsen et al. (1981) in the neuroblastoma $\times$ glioma hybrid. One is intimately related to the ligand-binding domain on the opiate receptor and the other is related to

\footnotetext{
' To whom correspondence should be addressed.

${ }^{2}$ Present address: Hematology Research, Evans Building, 75 East Newton Street, Boston, MA 02118.
}

a site involved in controlling opiate agonist affinity. The first descriptions of the importance of sulfhydryl groups to opiate receptors within the brain can be traced to demonstrations of specific binding of $\left[{ }^{3} \mathrm{H}\right]$ etorphine (Simon et al., 1973). These data indicate for the brain opiate receptor that there appears to be an essential - $\mathrm{SH}$ group close to or within the ligand-binding domain. Subsequently, Wilson et al. (1975) showed that sulfhydryl reagents differentiated agonist and antagonist interactions with respect to the opiate receptor by utilizing $\left[{ }^{3} \mathrm{H}\right]$ naloxone and $\left[{ }^{3} \mathrm{H}\right]$ dihydromorphine. While monovalent cations (Simon et al., 1975) and guanine nucleotides (Childers and Marsh, 1980; Zukin et al., 1980) selectively decrease agonist affinity (Pert and Snyder, 1974; Childers and Snyder, 1978, 1980), these agents, as well as agonists and antagonists (Pasternak et al., 1975; Simon et al., 1975), protect $-\mathrm{SH}$ groups related to opiate receptors from modification by NEM.

It has already been shown that both disulfide and sulfhydryl groups are intimately associated with the ability of the opiate receptors of tissue culture cells to form clusters on the surface of the plasma membrane (Hazum et al., 1979a, b, 1980). In situ modification of opiate receptors by phenoxybenzamine (Cicero et al., 1974) and a $\mathrm{Cu}^{2+}$.oxidized glutathione complex (Marzullo and Friedhoff, 1977) have a naloxone-blockable analgesic ac- 
tion (Elliot et al., 1976; Marzullo and Friedhoff, 1977; Marzullo and Hine, 1980). This suggests that an essential role of opiates may be their interaction with thiol groups associated with their receptors. We have therefore undertaken to examine in closer detail the - $\mathrm{SH}$ groups in the NG108-15 opiate receptors, paying special attention to the ability of ligands, cations, and GTP to protect these sites from modification. A preliminary report of these findings has been presented (Blume et al., 1981).

\section{Materials and Methods}

Cells and membranes. Crude membranes devoid of intact cells and nuclei were isolated from whole cell homogenates made from frozen mouse neuroblastoma $X$ glioma hybrid NG108-15 cells (Klee and Nirenberg, 1974) as previously detailed (Larsen et al., 1981). Protein determinations were by the method of Lowry et al. (1951).

Treatment with thiol reagents. The membranes were suspended at protein concentrations of 3 to $5 \mathrm{mg}$ of

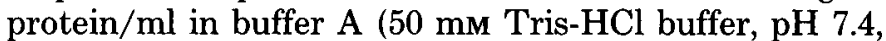
$2 \mathrm{mM}$ EDTA, and $0.4 \mathrm{mM}$ EGTA) containing no other additions or various opiates, cations, or GTP (as noted in the text) and then were incubated for 5 to $10 \mathrm{~min}$ at $32^{\circ} \mathrm{C}$. Afterwards, NEM or other thiol reagents (see the text) were added to a final concentration of $2 \mathrm{~mm}$ (unless specified otherwise) and the incubation was continued at $32^{\circ} \mathrm{C}$ for the various times noted. All thiol reactions were stopped by adding dithiothreitol (DTT) to a final concentration of $10 \mathrm{~mm}$. The controls for all of these treatments were duplicate incubation mixtures to which 10 mM D'T"I' (final concentration) was added prior to the addition of any other thiol reagent. No difference in binding was observed due to the presence or absence of $10 \mathrm{~mm}$ DTT. The membranes then were washed by one of the following two methods. In the cases where the reaction volumes were small (i.e., $0.1 \mathrm{ml}$ ) and contained in 1-ml Eppendorf conical tubes, they were diluted 10fold with buffer B (50 mM Tris- $\mathrm{HCl}$ buffer, $\mathrm{pH} 7.4$, with $2.5 \mathrm{mM} \mathrm{MgCl} ; 20^{\circ} \mathrm{C}$ ) and spun for $1 \mathrm{~min}$ in an Eppendorf microfuge. Thereafter, the supernatant was suctioned off, the pellet was suspended in buffer B and was vortexed, and the process of centrifugation and suspension was repeated three times. The final pellets were suspended in $0.08 \mathrm{ml}$ of buffer $\mathrm{A}$. Where the reaction volumes were large (i.e., 1 to $2 \mathrm{ml}$ ) and in 15-ml Corex tubes, they were diluted $\sim 10$ times as above in buffer $B$ and then centrifuged at $39,000 \times \mathrm{g}$ for $10 \mathrm{~min}$ at $4^{\circ} \mathrm{C}$. The resulting pellets were suspended in $10 \mathrm{ml}$ of buffer $B$ and recentrifuged. This procedures was repeated four times and the final pellet was suspended in buffer $A$ and rehomogenized. All washed membrane preparations were assayed immediately for binding.

Binding assays. The binding of ${ }^{3} \mathrm{H}$-ligands, at the concentrations noted in the text, was performed at $32^{\circ} \mathrm{C}$ for $20 \mathrm{~min}$ in reaction volumes of 0.10 to $0.15 \mathrm{ml}$. All binding reported is "specific" as defined by the difference $\pm 10 \mu \mathrm{M}$ etorphine $/ \mathrm{HCl}$. When the membranes were in microfuge tubes, the assays were performed therein and the reactions were initiated by the addition of the ${ }^{3} \mathrm{H}$ ligand. Otherwise, assays were in plastic tubes and the reactions were initiated by the addition of the washed membrane preparation. In all cases, separation of bound and free ${ }^{3} \mathrm{H}$-ligand was accomplished by rapid filtration over Whatman GF/B filters as described previously (Larsen et al., 1981).

Materials. $\left[{ }^{3} \mathrm{H}\right] \mathrm{Naloxone}(50 \mathrm{Ci} / \mathrm{mmol})$ and the enkephalin analogue TyrDalaGlyPheMetNH ${ }_{2} \quad\left[{ }^{3} \mathrm{H}\right]$ Dala ${ }^{2}$ met $^{5}$ amide) (30 to $50 \mathrm{Ci} / \mathrm{mmol}$ ) were obtained from New England Nuclear, Boston, MA. $N$-Ethylmaleimide, iodoacetamide, and para-chloromercuribenzoic acid were purchased from Sigma Chemical Co., St. Louis, MO, and Dala ${ }^{2}$ met $^{5}$ amide was from Boehringer Mannheim Biochemicals, Indianapolis, IN. The following were gifts: naltrexone $/ \mathrm{HCl}$ and naloxone $/ \mathrm{HCl}$ from Endo Pharmaceuticals, Garden City, NY; cyclazocine and pentazocine from Sterling Winthrop Research Institute, Rensselear, $\mathrm{NY}$; and etorphine $/ \mathrm{HCl}$, normorphine, and human $\beta$ endorphin from Hoffmann-La Roche Inc., Nutley, NJ. $\left[{ }^{3} \mathrm{H}\right]$ Naltrexone $(25 \mathrm{Ci} / \mathrm{mmol})$ was a gift from the $\mathrm{Na}$ tional Institute of Drug Abuse, Bethesda, MD. All other chemicals were of the highest available purity.

\section{Results}

NG108-15 membranes lose the ability to bind all types of opiates when incubated with $n$-ethylmaleimide (NEM). Interestingly, in such experiments the binding of opiate agonists is lost faster than is the binding of opiate antagonists when measured with subsaturating concentrations of ${ }^{3} \mathrm{H}$-ligands (Fig. 1). For example, with membranes treated with $2 \mathrm{mM}$ NEM, binding of the enkeph-

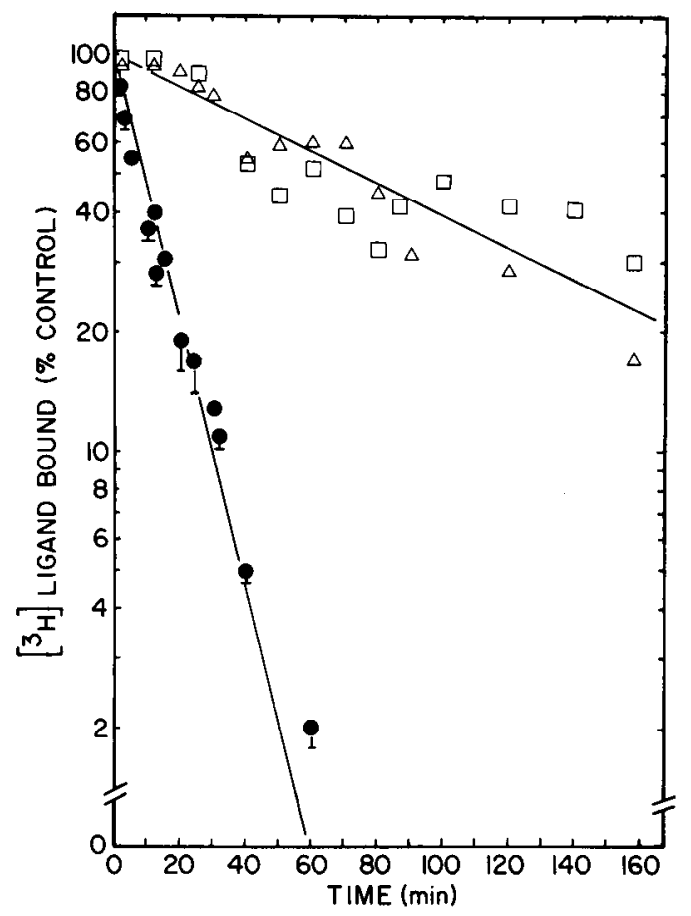

Figure 1. Losses in opiate agonist and antagonist binding induced by NEM. Membranes were incubated in buffer with 2 mM NEM for the times indicated. After washing three times, using the microfuge technique (see "Materials and Methods"), the binding of $\left[{ }^{3} \mathrm{H}\right]$ Dala ${ }^{2}$ met $^{5}$ amide $(9.5$ to $13.7 \mathrm{nM})(0),\left[{ }^{3} \mathrm{H}\right]$ naloxone (8 to $10 \mathrm{nM})(\square)$, and $\left[{ }^{3} \mathrm{H}\right]$ naltrexone $(5$ to $7 \mathrm{nM})(\triangle)$ was assayed. The data are the mean \pm SEM obtained from three separate experiments and are given as percentages of the binding seen in control membranes. 
alin analogue Dala ${ }^{2}$ met ${ }^{5}$ amide disappears with a pseudofirst order rate constant of $0.08 \mathrm{~min}^{-1}$. In contrast, the binding of the antagonist naloxone or naltrexone decays almost 9 times slower (rate constant $=0.009 \mathrm{~min}^{-1}$ ) when exposed to the same amount of NEM. In a predictable manner, the binding of opiate agonists is more sensitive than the binding of antagonists to treatment with increasing concentrations of NEM for fixed times (Fig. 2). In these cases, the differential sensitivity to NEM is seen as a lower $\mathrm{IC}_{50}$ for inhibition of agonist binding (i.e., $\mathrm{IC}_{50}$ $=0.3 \mathrm{~mm}$ ) than antagonist binding (i.e., $\mathrm{IC}_{50}=0.65 \mathrm{~mm}$ ).

Not all thiol-reactive compounds so differentiate the binding of an opiate agonist from an opiate antagonist. When NG108-15 membranes are incubated with increasing concentrations of para-chloromercuribenzoic acid (PCMB), binding of both Dala ${ }^{2} \mathrm{met}^{5}$ amide and naloxone is lost. However, the interaction of the receptor with both ligands is inhibited in a like manner: the $\mathrm{IC}_{50}$ for PCMB, in each case, is $0.3 \mathrm{~mm}$. Finally, there are thiol reagents which have no visible effect on the opiate receptors in NG108-15 membranes under our assay conditions. Iodoacetamide appears to be one of these compounds as concentrations of up to $10 \mathrm{~mm}$ do not alter the binding of either Dala ${ }^{2}$ met ${ }^{5}$ amide or naloxone (Fig. 2).

The disappearance of ${ }^{3} \mathrm{H}$-opiate antagonist binding which accompanies the treatment of membranes with NEM is due solely to a loss in the number of opiate binding sites (Fig. 3). Before NEM treatment, the number of agonist and antagonist binding sites are equal ( 2 $\mathrm{pmol} / \mathrm{mg}$ of protein), and the apparent $K_{D}$ for naloxone at these sites is approximately $30.4 \mathrm{~nm}$ (Fig. 3) After incubation with $2 \mathrm{mM}$ NEM for $20 \mathrm{~min}$, naloxone still has the same or even a slightly better receptor affinity, but there are fewer binding sites. Longer treatment with 2 mM NEM causes bigger losses in receptor number (Lar-

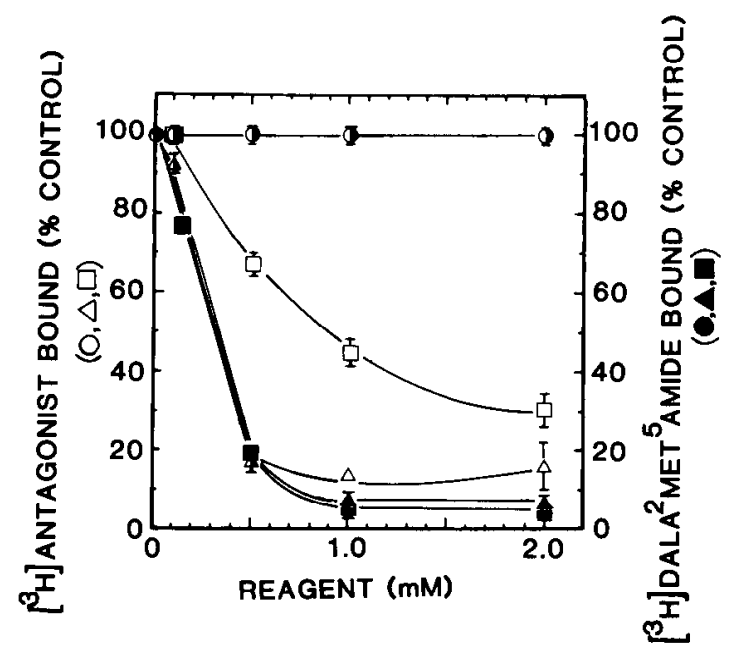

Figure 2. Susceptibility of opiate agonist and antagonist binding to different thiol reagents. Membranes were incubated in buffer for $20 \mathrm{~min}$ with increasing concentrations of either $\operatorname{NEM}(\square, \square), \operatorname{PCMB}(\Lambda, \Delta)$ or iodoacetamide $(0,0)$. After washing three times using the microfuge technique (see "Materials and Methods"), the membranes were assayed for the binding of $\left[{ }^{3} \mathrm{H}\right] \mathrm{Dala}{ }^{2} \mathrm{met}^{5}$ amide (2 to $5 \mathrm{nM}$ ) (solid symbols) and $\left[{ }^{3} \mathrm{H}\right]$ naltrexone (2 to $5 \mathrm{nM}$ ) (open symbols). The data are given as a percentage \pm SEM of the binding seen in control membranes. This experiment was repeated twice.

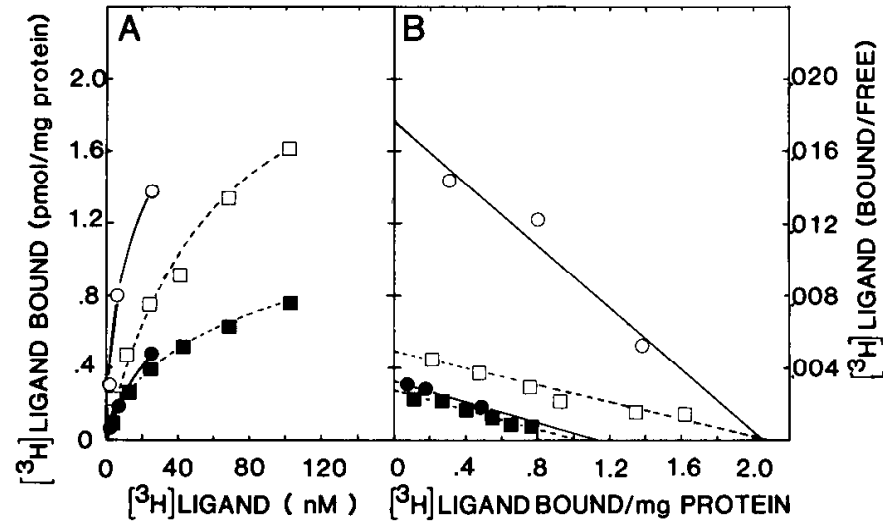

Figure 3. Losses in binding sites and affinity induced by NEM. Membranes were incubated in buffer for 20 min with 2 mM NEM; appropriate controls (see "Materials and Methods") also were included. Afterwards, the membranes were washed and the specific binding of $\left[{ }^{3} \mathrm{H}\right]$ Dala ${ }^{2}$ met ${ }^{5}$ amide and $\left[{ }^{3} \mathrm{H}\right]$ naloxone was determined over the concentration range 1 to 100 nM. The data are given as saturation binding isotherms $(A)$ and Scatchard plots $(B) .\left[{ }^{3} \mathrm{H}\right]$ Dala ${ }^{2}$ met $^{5}$ amide binding to control $(O)$ or NEM-treated membranes $(O)$ and $\left[{ }^{3} \mathrm{H}\right]$ naloxone binding to control $(\square)$ or NEM-treated membranes $(\square)$ are indicated. For $\left[{ }^{3} \mathrm{H}\right]$ Dala ${ }^{2}$ met ${ }^{5}$ amide, average $K_{D}$ values are $5.6 \pm 1.4$ and $18.8 \pm 6.7 \mathrm{nM}$ for control and NEM-treated membranes, respectively. Values for $\left[{ }^{3} \mathrm{H}\right]$ naloxone are $30.4 \pm 5$ and $28 \pm 3 \mathrm{nM}$ for control and NEM-treated membranes, respectively.

sen et al., 1981). In agreement with the known ability of NEM to alkylate thiol groups covalently, the above effects are not reversed upon washing the membranes free of this reagent or by adding DTT. The degree of reduction in the number of receptors is the same when judged by the binding of ${ }^{3} \mathrm{H}$-opiate agonist or antagonist (Larsen et al., 1981).

Losses in $\left[{ }^{3} \mathrm{H}\right] \mathrm{Dala}{ }^{2} \mathrm{met}^{5}$ amide binding directed by NEM stem not only from the above documented loss in receptor number but also from another action of NEM. At those binding sites which remain after NEM treatment, the affinity for Dala ${ }^{2}$ met $^{5}$ amide is 2- to 6-fold less than that seen with control membranes (Fig. 3). This condition is not reversed by washing the membranes free of the reagent or by adding DTT. Such losses in affinity due to incubation with NEM are observed with numerous opiate agonists and apparently are not specific for any one class of opiate agonist (Larsen et al., 1981).

In an attempt to delineate the sites of action of NEM involved in these two processes (i.e., reduction in receptor number vs. affinity), we analyzed the ability of different agents to protect against one or both of these actions. In these experiments, membranes were incubated with or without various opiate ligands, cations, or GTP and 2 mM NEM for various times. The residual binding of subsaturating concentrations of $\left[{ }^{3} \mathrm{H}\right]$ naloxone was monitored to assess the quantity of receptors protected. On the other hand, when protection of agonist affinity was of interest, the residual binding of subsaturating concentrations of $\left[{ }^{3} \mathrm{H}\right] \mathrm{Dala}^{2} \mathrm{met}^{5}$ amide was monitored. The following are noteworthy in relation to the protection afforded by various ligands. (1) The presence of naltrexone (at $\sim 5$ times its $K_{D}$ ) during NEM treatment provides little protection of ${ }^{3} \mathrm{H}$-agonist binding. The $t_{1 / 2}$ for loss in 
$\left[{ }^{3} \mathrm{H}\right] \mathrm{Dala}{ }^{2} \mathrm{met}^{5}$ amide binding increases from 12 to $18 \mathrm{~min}$ (Fig. 4A). Yet, this amount of naltrexone completely protects against losses in ${ }^{3} \mathrm{H}$-antagonist binding for as long as $150 \mathrm{~min}$ (Fig. $4 B$ ). (2) The presence of Dala ${ }^{2} t^{5}$ amide (at $\sim 10$ times its $K_{D}$ ) affords a great deal of protection for both $\left[{ }^{3} \mathrm{H}\right]$ Dala ${ }^{2} \operatorname{met}^{5}$ amide and $\left[{ }^{3} \mathrm{H}\right]$ naloxone binding. In these instances, the rate of decay of ${ }^{3} \mathrm{H}$-agonist binding is decreased by almost 6 -fold (Fig. $4 A$ ), while there is almost no loss in ${ }^{3} \mathrm{H}$-antagonist binding for up to $80 \mathrm{~min}$ (Fig. $4 B$ ). Therefore, both naltrexone and Dala ${ }^{2}$ met $^{5}$ amide appear more efficient at protecting antagonist than agonist binding from inactivation and/ or modification by NEM. That Dala ${ }^{2}$ met $^{5}$ amide can provide protection for such long times is in agreement with our ability to follow its binding and regulation of adenylate cyclase activity at $32^{\circ} \mathrm{C}$ for as long as $60 \mathrm{~min}$ (unpublished results). The increases in specific binding of $\left[{ }^{3} \mathrm{H}\right]$ naloxone after short times with NEM (i.e., $\leq \mathbf{4 0} \mathrm{min}$ ) is not unexpected as such treatments cause up to a 2 -fold increase in the affinity for antagonists (Larsen et al., 1981).

We have also assessed the ability of other ligands (at $\sim 10$ times their $K_{D}$ ) to protect against any NEM-induced loss of ${ }^{3} \mathrm{H}$-opiate agonist binding (Table I). These results clearly illustrate that many different opiates can protect against the loss of agonist binding. Included among these is the larger endogenous opioid $\beta$-endorphin and the two nonpeptide opiates normorphine and etorphine. In addition, some protection, although not as great as that seen with full agonists, is provided by ligands with mixed agonist and antagonist properties (i.e., cyclazocine and pentazocine). Pure opiate antagonists (i.e., naltrexone and naloxone) also provide some protection.

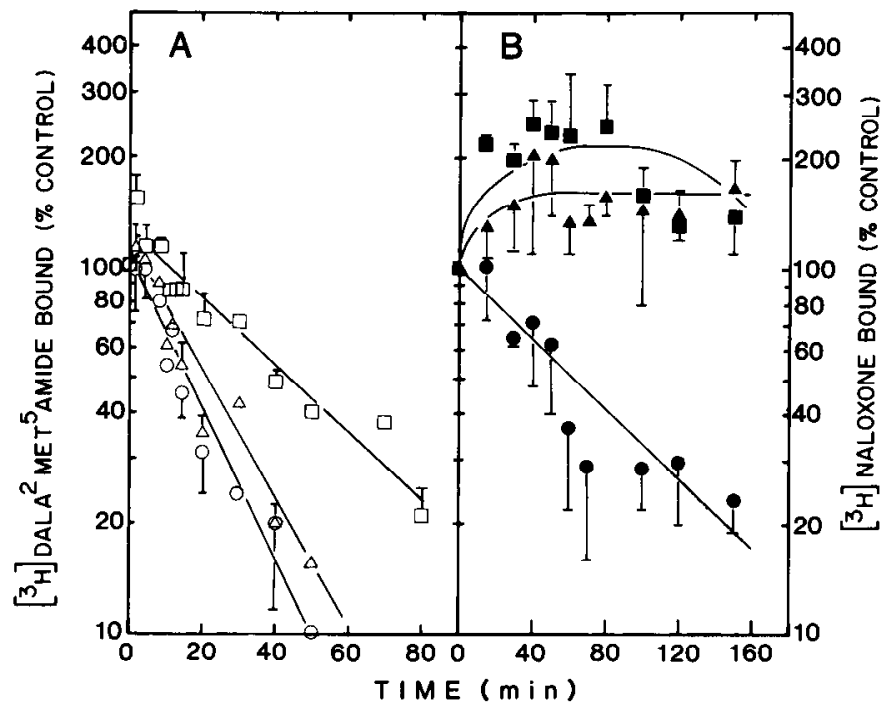

Figure 4. Protection by ligands against the actions of NEM. Membranes were incubated for $10 \mathrm{~min}$ at $32^{\circ} \mathrm{C}$ without any ligands $(O, O)$ or with $50 \mathrm{~nm} \operatorname{Dala}^{2}$ met $^{5}$ amide $(\square, \square)$ or $150 \mathrm{nM}$ naltrexone $(\triangle, \Delta)$. NEM $(2 \mathrm{mM})$ was added and the incubation was continued for up to $150 \mathrm{~min}$ as noted. After washing three times (microfuge method) membranes were assayed for the binding of either $\left[{ }^{3} \mathrm{H}\right] \mathrm{Dala}{ }^{2} \mathrm{met}^{5}$ amide (9.5 to $13.7 \mathrm{nM}$ ) (open symbols) or $\left[{ }^{3} \mathrm{H}\right]$ naloxone ( 7 to $8 \mathrm{nM}$ ) (solid symbols). Data are the mean \pm SEM from three separate experiments and are expressed as a percentage of the binding seen in control membranes.
TABLE I

Protection by ligands against losses in $\left[^{3} \mathrm{H}\right] \mathrm{Dala}^{2}$ met ${ }^{5}$ amide binding induced by $N$-ethylmaleimide

Membranes were incubated first with the various ligands noted and thereafter were incubated with $2 \mathrm{mM}$ NEM. After $20 \mathrm{~min}$ of NEM treatment, they were washed by the microfuge technique (see "Materials and Methods") and then assayed for $\left[{ }^{3} \mathrm{H}\right] \mathrm{Dala}^{2} \mathrm{met}^{5}$ amide binding (6.4 to $10 \mathrm{~nm}$ ). Appropriate controls were included (see "Materials and Methods").

\begin{tabular}{|c|c|c|c|}
\hline \multirow{3}{*}{ Protecting Ligand } & \multicolumn{3}{|c|}{$\begin{array}{c}{\left[{ }^{3} \mathrm{H}\right] \text { Dala }{ }^{2} \text { met }{ }^{5} \text { amide Bound }} \\
\text { (\% Control) }\end{array}$} \\
\hline & \multicolumn{3}{|c|}{ Experiment Number } \\
\hline & 1 & 2 & 3 \\
\hline None & 35 & 24 & 32 \\
\hline \multicolumn{4}{|l|}{ Agonists } \\
\hline Dala ${ }^{2}$ met $^{5}$ amide (50 nM) & 78 & 62 & 98 \\
\hline$\beta$-endorphin (300 nM) & 65 & $\mathrm{ND}^{\alpha}$ & ND \\
\hline Etorphine (30 nM) & 56 & 59 & 80 \\
\hline Normorphine $(7 \mu \mathrm{M})$ & 59 & 62 & 89 \\
\hline \multicolumn{4}{|l|}{ Agonists-antagonists } \\
\hline Pentazocine $(1.7 \mu \mathrm{M})$ & ND & 53 & 78 \\
\hline Cyclazocine (80 nM) & ND & 26 & 64 \\
\hline \multicolumn{4}{|l|}{ Antagonists } \\
\hline Naltrexone (150 nM) & ND & 47 & 50 \\
\hline Naloxone (400 nM) & ND & ND & 67 \\
\hline
\end{tabular}

${ }^{a} \mathrm{ND}$, not determined.

As losses in ${ }^{3} \mathrm{H}$-antagonist binding simply reflect losses in receptor number, the protection of $\left[{ }^{3} \mathrm{H}\right]$ naloxone binding should be due to retention of the control number of receptors. To test this prediction, membranes were treated with NEM in the presence or absence of either Dala ${ }^{2}$ met $^{5}$ amide or naltrexone for $80 \mathrm{~min}$ (Fig. 5). During these incubations, in the absence of any ligands, the number of sites is reduced to $\leq 1 / 3$ of normal. In all of these experiments, the membranes were washed five times to ensure as complete removal of the free ligands as possible. Clearly, the presence of either the opioid peptide or the opiate antagonist increases the number of receptors which survive this treatment. In agreement with experiments previously described, there is no significant loss in antagonist affinity after this NEM treatment. However, sometimes when protecting ligands are present during the incubation stage, there are less receptors than are seen in controls. As there is no corresponding loss in $\left[{ }^{3} \mathrm{H}\right]$ naloxone affinity, these losses in receptors cannot be due to free protecting ligand contaminating the assay stage of the experiment.

In similar experiments, we looked to see if protection by agonists against losses in ${ }^{3} \mathrm{H}$-agonist binding reflects a protection of either receptor number, affinity, or both. The inclusion of the opioid peptide during NEM treatment leads to an increase in the number of receptors left and prevents some of the normal decrease in Dala ${ }^{2}$ met $^{5}$ amide affinity (data not shown). For example (as shown in Fig. 6), the $K_{D}$ for the opioid peptide is $\sim 5$ nM in control, while after NEM treatment it can be $\sim 20$ nM. Yet when these membranes are treated with NEM in the presence of the opioid peptide, the $K_{D}$ is $\sim 12 \mathrm{nM}$. Some of this variability may relate to difficulties in removing all of the "protecting" ligand. At present, we cannot reach any firm conclusion as to the ability of the agonist to protect against losses in agonist affinity, but it 


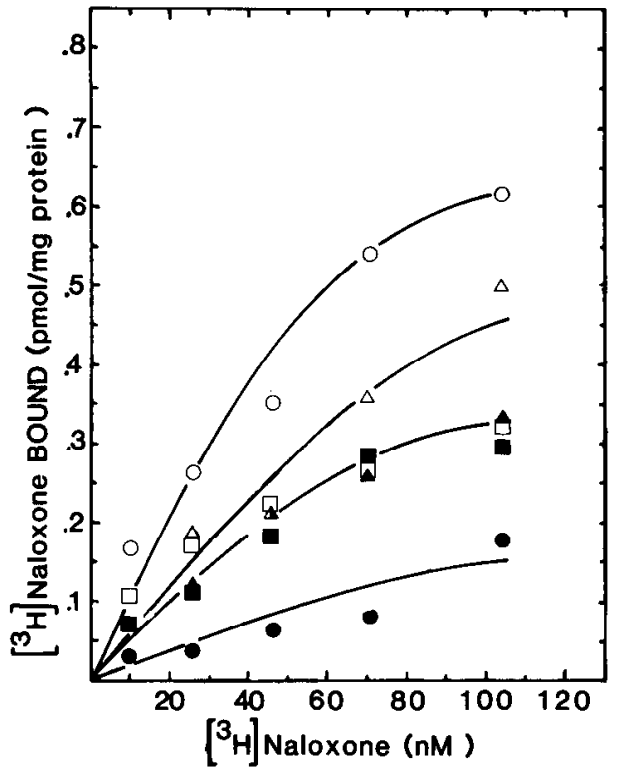

Figure 5. Saturation binding of $\left[{ }^{3} \mathbf{H}\right]$ naloxone to membranes treated with $\mathrm{NEM} \pm$ other ligands. Membranes were incubated in 15-ml Corex test tubes for $80 \mathrm{~min}$ in buffer containing $2 \mathrm{mM}$ NEM alone (O) or with $50 \mathrm{~nm}$ Dala $^{2}$ met $^{5}$ amide ( $\square$ ) or $8000 \mathrm{nM}$ naltrexone (A). Appropriate controls (see "Materials and Methods") were run without ligand $(O)$ or with opioid peptide ( $\square$ ) or naltrexone $(\triangle)$. After washing five times (see "Materials and Methods"), the membranes were assayed for [ $\left.{ }^{3} \mathrm{H}\right]$ naloxone binding over the concentration range of 10 to $100 \mathrm{nM}$. Dissociation constants $\left(K_{D}, \mathrm{nM}\right)$ with Dala met ${ }^{5}$ amide are 17.4 for control and 14.5 for NEM-treated membranes. Values for naltrexone are 18.1 and $10.8 \mathrm{nM}$ for control and NEM-treated membranes, respectively.

is clear that they protect against losses in receptor number.

The results of studies on the effectiveness of cations and GTP as "protectors" against NEM are summarized in Figure 7 and Table II. The presence of $0.4 \mathrm{M} \mathrm{NaCl}$ has only a very minimal effect on the loss in ${ }^{3} \mathrm{H}$-agonist binding; it decreases the rate of loss in $\left[{ }^{3} \mathrm{H}\right]$ Dala ${ }^{2}$ met $t^{5}$ amide binding by $\sim 50 \%$. This apparently would indicate that $\mathrm{NaCl}$ cannot protect the high affinity form of agonist binding from modification by NEM. This has been confirmed directly by monitoring the saturation binding isotherms for Dala ${ }^{2} t^{5}$ amide and the competition by this peptide for $\left[{ }^{3} \mathrm{H} /\right.$ naloxone binding to membranes treated with NEM in the presence of $\mathrm{NaCl}$ (data not shown). GTP $(0.2 \mathrm{~mm})$ appears to increase by 2 -fold the rate of loss of the binding of ${ }^{3} \mathrm{H}$-agonist (Fig. 7A). Sodium chloride, however, affords almost complete protection against the NEM-directed losses in $\left[{ }^{3} \mathrm{H}\right]$ naloxone binding. The rank order for monovalent cations as protecting agents against losses in ${ }^{3} \mathrm{H}$-antagonist binding is $\mathrm{Na}^{+} \geq \mathrm{Li}^{+}>\mathrm{K}^{+} \gg$ choline ${ }^{+}$(Table II). The maximal protection afforded by $\mathrm{Na}^{+}$and $\mathrm{Li}^{+}$is approximately equal, whereas $\mathrm{K}^{+}$and choline ${ }^{+}$have a much lower protective efficacy. GTP does not provide significant protection against losses in $\left[{ }^{3} \mathrm{H}\right]$ naloxone binding.

\section{Discussion}

Previously it was reported (Larsen et al., 1981) that the opiate receptors in NG108-15 are susceptible to mod-

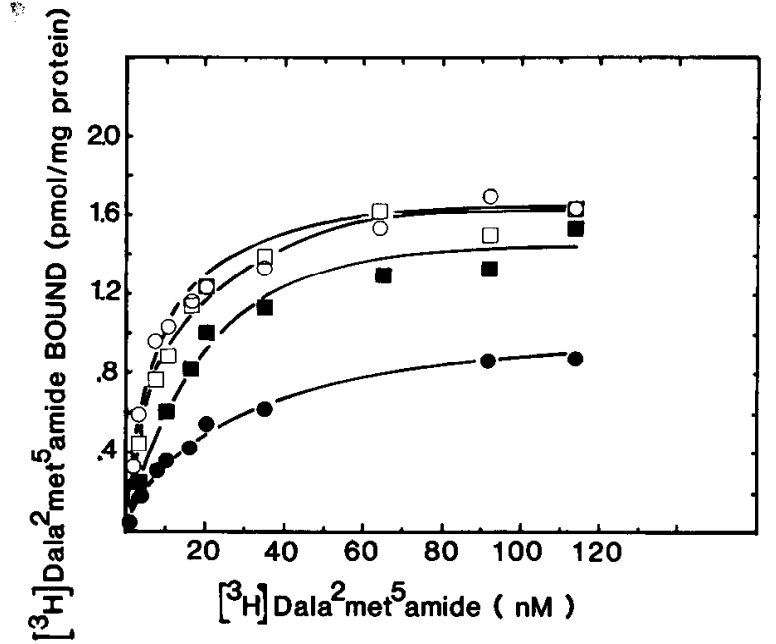

Figure 6. Saturation binding of $\left[{ }^{3} \mathrm{H}\right]$ Dala ${ }^{2}$ met ${ }^{5}$ amide to membranes incubated with $\mathrm{NEM} \pm$ opioid peptide. Membranes were treated as described in the legend to Figure 5 with the exception that the incubation period with NEM was only 20 min. Membranes incubated without NEM (O) plus Dala $^{2}$ met $^{5}$ amide $(\square)$ and with NEM (O) plus Data ${ }^{2}$ met $^{5}$ amide (口) are indicated. Average $K_{\nu}$ values for control and NEM treated plus Dala ${ }^{2}$ met $^{5}$ amide are $6.1 \pm 2.1$ and $22.6 \pm 10 \mathrm{nM}$, respectively.

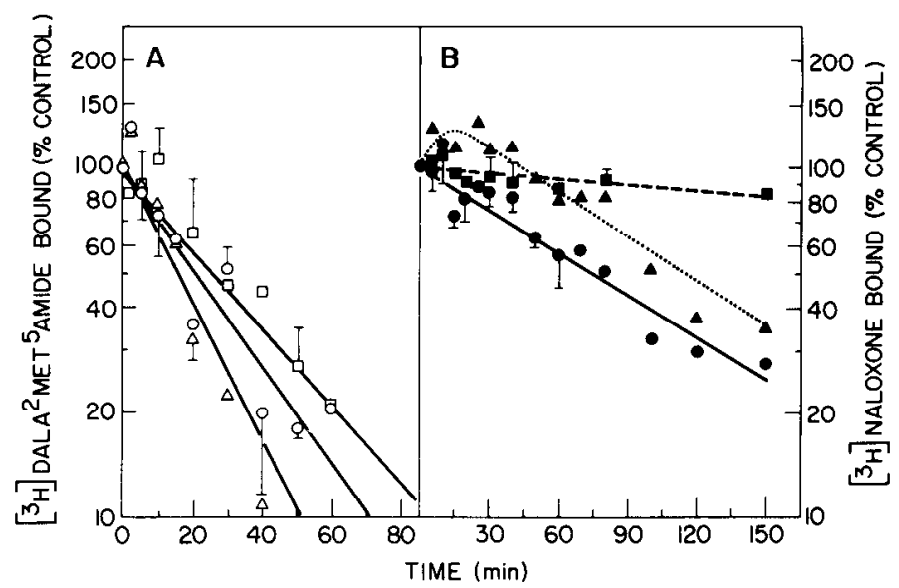

Figure 7. Protection by $\mathrm{NaCl}$ against NEM-induced losses in ${ }^{3} \mathrm{H}$-ligand binding. Membranes were incubated in buffer alone $(\bigcirc, \bigcirc)$ or with $0.4 \mathrm{~m} \mathrm{NaCl}(\square, \square)$ or $0.2 \mathrm{~mm} \mathrm{GTP}(\triangle, \Delta)$ with 2 $\mathrm{mM}$ NEM for up to $150 \mathrm{~min}$. After washing, the membranes were assayed for $\left[{ }^{3} \mathrm{H}\right] \mathrm{Dala}^{2} \mathrm{met}^{5}$ amide $(A)$ (6 to $13 \mathrm{nM}$ ) (open symbols) or $\left[{ }^{3} \mathrm{H}\right]$ naloxone $(B)(5$ to $10 \mathrm{nM})$ (solid symbols) binding. The data are presented as the mean \pm SEM from three separate experiments and are given as a percentage of the binding seen in controls. The $y$ intercepts for control, $\mathrm{Na}^{+}$ treated, and GTP treated are $92.3,92$, and $98 \%$, respectively. Correlation coefficients for all three lines are greater than 0.87 .

ification by $\mathrm{N}$-ethylmaleimide. Two different actions of NEM, both assumed to involve sulfhydryl groups, were described at that time: one to decrease the number of opiate receptors and the other to decrease the affinity of these receptors for agonist ligands. The data presented in this report are not only in complete agreement with the original observations, but they also better define the individuality of these two actions of NEM. 
TABLE II

Specificity of protection of $\left[{ }^{3} \mathrm{H}\right]$ naloxone binding from NEM inactivation afforded by monovalent cations

Membranes were incubated with the cation listed below at $32^{\circ} \mathrm{C}$ in the presence of $2 \mathrm{mM} \mathrm{NEM}$ for $80 \mathrm{~min}$. After stopping the reaction, the membranes were washed by the microfuge method (see "Materials and Methods") and then assayed for the binding of $\left[{ }^{3} \mathrm{H}\right]$ naloxone (9.2 nM). All cations were added as chloride salts and appropriate controls were performed as detailed under "Materials and Methods."

\begin{tabular}{lcc}
\hline \multicolumn{1}{c}{ Cation } & $\mathrm{mM}$ & $\begin{array}{c}{\left[{ }^{3} \mathrm{H}\right] \text { Naloxone Bound }} \\
\text { (\% Control) }\end{array}$ \\
\hline None & & 29 \\
$\mathrm{Na}^{+}$ & 2 & 86 \\
& 10 & 81 \\
& 50 & 100 \\
$\mathrm{Li}^{+}$ & 10 & 51 \\
& 50 & 84 \\
& 100 & 89 \\
$\mathrm{~K}^{+}$ & 10 & 38 \\
& 50 & 36 \\
& 100 & 46 \\
Choline $^{+}$ & 10 & 21 \\
& 50 & 40 \\
& 100 & 36 \\
\hline
\end{tabular}

Our early speculation that the sites of action of NEM were sulfhydryl groups is supported now by the finding that both PCMB (which forms $\mathrm{Hg}^{2+}$ adducts with - SH groups) and NEM (which alkylates $-\mathrm{SH}$ groups) decrease the binding of agonists and antagonists to opiate receptors. Also, as would be expected with such covalent actions, these effects are (1) time and concentration dependent, (2) stopped by dithiothreitol, and (3) not reversed by washing away the free agent.

The postulated - SH groups appear to be directly accessible for modification. Alteration of the receptor subsequent to binding an opiate is not required for these - SH groups to be reactive. The hypothesis that there is one such - SH group per ligand-binding domain on each receptor is substantiated by the following data on the action of NEM. Losses in binding of two different opiate antagonists, naloxone and naltrexone, are described by the same pseudo-first order rate constant. The losses in binding subsaturating concentrations of ${ }^{3} \mathrm{H}$-antagonists correlate quantitatively with the reductions in the number of receptors seen after treatment with NEM (Larsen et al., 1981). No losses in affinity accompany these modifications. Therefore, the alteration by NEM (or PCMB) of only one such - SH group appears sufficient to modify the binding site. Iodoacetamide, for as yet unexplained reasons, either cannot alter these groups or its modification produces binding sites that are still within tolerable limits. Finally, a wide variety of opiate ligands protect against this action of NEM. This indicates that these - SH groups are in close proximity to or are within the ligand-binding domain of the receptor. Among those ligands capable of protecting the binding site (i.e., those which prevent losses in receptor number) are alkaloids and peptide agonists as well as two pure opiate antagonists. If one assumes that the interaction of antagonist and receptor is a purely passive event, then the simplest explanation of these data would be that ligands mask the target - SH group when occupying the binding site. Under such circumstances, there would be no need to postulate any allosteric alteration of the $-\mathrm{SH}$ group in response to ligand binding. Although in some cases agonists protect better than antagonists, it must be remembered that the action of NEM is irreversible, while ligand binding is reversible. This often translates into an advantage for agonists over antagonists in acting as "protectors" as the former generally dissociate from the receptor much more slowly than do either of the two antagonists that were used.

The occurrence of an essential - SH group within the ligand-binding domain of the NG108-15 opiate receptor is very analogous to the situation found with opiate receptors in brain and other tissues (Simon et al., 1973, 1975; Wilson et al., 1975). All of these opiate receptors have accessible - SH sites which when modified by NEM alter the binding site. Apparently, opiate agonists and antagonists protect against such modifications. Interestingly, an early observation concerning these - $\mathrm{SH}$ groups was that they were protected from NEM best by those monovalent cations which would selectively decrease agonist affinity for these opiate receptors (Simon et al., 1975; Spiehler et al., 1978). In strengthening the analogy between NG108-15 and brain opiate receptors, we find that the same is true with the NG108-15 binding sites: sodium and lithium offer a great deal of protection against the action of NEM, while potassium and choline offer much less. The former two ions selectively decrease opiate agonist binding in NG108-15 by some type of allosteric mechanism (Blume, 1978). Protection of the binding site of the NG108-15 opiate receptors by monovalent cations gives additional support to the idea that the opiate receptor, per se, is the site of action of sodium.

As noted earlier, our initial investigation also indicated that there was a second action of NEM: one which was related specifically to agonist high affinity. At that time (Larsen et al., 1981), it was shown that agonist affinity could be greatly diminished without there being a corresponding change in antagonist affinity or loss in receptor number. In addition, these altered sites not only retained their $\mathrm{Na}^{+}$sensitivity (i.e., further losses in agonist affinity could be induced by $\mathrm{Na}^{+}$) but were, in fact, much more sensitive to monovalent cations. However, these altered states could not be regulated by GTP; the nucleotide normally decreases agonist affinity. Based on the above, we speculated that another - $\mathrm{SH}$ group, different from the one related to the binding site, was involved in these reactions. The data presented here support the existence of this second - $\mathrm{SH}$ group as being somewhere within the opiate receptor complex but not at the ligand-binding site. Not only can NEM distinguish between these two - SH groups, but protection of these two sites by ligands and cations is clearly different. Whereas antagonists and monovalent cations afford excellent protection of the $-\mathrm{SH}$ group within the binding site, neither are effective protectors of the $-\mathrm{SH}$ group responsible for binding agonist with high affinity. As GTP does not protect either - SH group nor do agonists clearly protect the high affinity state, the actual location of this second - $\mathrm{SH}$ group remains ambiguous. Although 
it is outside of the general ligand-binding domain, it could lie within another domain of the receptor or some other protein associated with the receptor moiety. With the brain opiate receptors, GTP protects against losses in agonist and antagonist binding induced by NEM (Childers and Marsh, 1980; Zukin et al., 1980). Therefore, these receptors apparently do associate with a nucleotide-binding component and, furthermore, such associations are involved in high affinity opiate agonist binding. Most likely an association exists between the NG108-15 opiate receptor and a nucleotide-binding protein. With great specificity, guanine nucleotides clearly modify opiate agonist binding to NG108-15 receptors (Blume, 1978; Blume et al., 1979a). In addition, the alkylation of a single - SH group outside of the opiate ligand-binding domain causes both a loss in agonist affinity and a loss in nucleotide sensitivity. Certainly, such events would be explained if modification of these - $\mathrm{SH}$ groups prevented the proper association of the receptor with the nucleotide-binding protein. Coupling of such regulatory components with other receptors which control the activity of adenylate cyclase has, in fact, been shown to be responsible for high affinity agonist binding and its sensitivity to guanine nucleotides (Ross et al., 1978; Stadel and Lefkowitz, 1979; De Lean et al., 1980; Citri and Schramm, 1980). Resolution of these issues must await the solubilization of some of these components in an active form.

\section{References}

Blume, A. J. (1978) Opiate binding to membrane preparations of neuroblastoma $\times$ glioma hybrid cells NG108-15: Effects of ions and nucleotides. Life Sci 22: 1843-1852.

Blume, A. J., G. Boone, and D. Lichshtein (1979a) Regulation of the neuroblastoma $\times$ glioma hybrid opiate receptors by $\mathrm{Na}^{+}$and guanine nucleotides. In Modulators, Mediators and Specifiers in Brain Function, Y. H. Ehrlich, J. Volvaka, L. G. Davis, and E. G. Brunngraber, eds., pp. 163-174, Plenum Press, New York.

Blume, A. J., D. Lichshtein, and G. Boone (1979b) Coupling of opiate receptors to adenylate cyclase: Requirement for $\mathrm{Na}^{+}$ and GTP. Proc. Natl. Acad. Sci. U. S. A. 76: 5626-5630.

Blume, A. J., D. Mullikin-Kilpatrick, and N. E. Larsen (1981) The involvement of sulphydryl groups in the functional integrity of the opiate receptors of neuroblastoma $\times$ glioma hybrid NG108-15. In Molecular Pharmacology of Neurotransmitter Receptor Systems, J. Jacob, K. Kuriyama, T. Segawa, and H. I. Yamamura, eds., in press.

Chang, K. J., and P. Cuatrecasas (1979) Multiple opiate receptors: Enkephalins and morphine bind to receptors of different specificity. J. Biol. Chem. 254: 2610-2618.

Chang, K. J., R. J. Miller, and P. Cuatrecasas (1978) Interaction of enkephalin with opiate receptors in intact cultured cells. Mol. Pharmacol. 14: 961-970.

Childers, S. R., and M. Marsh (1980) Characterization of guanine nucleotide interactions with opiate receptors in rat brain. Soc. Neurosci. 6: 524 .

Childers, S. R., and S. H. Snyder (1978) Guanine nucleotides differentiate agonist and antagonist interactions with opiate receptors. Life Sci., 23: 759-762.

Childers, S. R., and S. H. Snyder (1980) Differential regulation by guanine nucleotides of opiate agonist and antagonist receptor interactions. J. Neurochem. 34: 583-593.

Cicero, T. J., C. E. Wilcox, and E. R. Meyer (1974) Effect of $\alpha$ - adrenergic blockers on naloxone binding in brain. Biochem. Pharmacol. 23: 2349-2352.

Citri, Y., and M. Schramm (1980) Resolution, reconstitution, and kinetics of the primary action of a hormone receptor. Nature 287: 297-300.

De Lean, A., J. M. Stadel; and R. J. Lefkowitz (1980) A ternary complex model explains the agonist-specific binding properties of the adenylate cyclase-coupled $\beta$-adrenergic receptor. J. Biol. Chem. 255: 7108-7117.

Elliot, H. W., V. Spiehler, and G. Navarro (1976) Effect of naloxone on antinociceptive aclivily of phenoxybenzamine. Life Sci. 19: 1637-1644.

Hazum, E., K. J. Chang, and P. Cuatrecasas (1979a) Opiate (enkephalin) receptors of neuroblastoma cells: Occurrence in clusters on the cell surface. Science 206: 1077-1079.

Ilazum, E., K. J. Chang, and P. Cuatrecasas (1979b) Role of disulphide and sulphydryl groups in clustering of enkephalin receptors in neuroblastoma cells. Nature 282: 626-628.

Hazum, E., K. J. Chang, and P. Cuatrecasas (1980) Cluster formation of opiate (enkephalin) receptors in neuroblastoma cells: Differences between agonists and antagonists and possible relationships to biological functions. Proc. Natl. Acad. Sci. U. S. A. 77: 3038-3041.

Klee, W. A., and M. Nirenberg (1974) A neuroblastoma $\times$ glioma hybrid cell line with morphine receptors. Proc. Natl. Acad. Sci. U. S. A. 71: 3474-3477.

Koski, G., and W. A. Klee (1981) Opiates inhibit adenylate cyclase by stimulating GTP hydrolysis. Proc. Natl. Acad. Sci. U. S. A. 78: 4185-4189.

Larsen, N. E., D. Mullikin-Kilpatrick, and A. J. Blume (1981) Two different modifications of the neuroblastoma $\times$ glioma hybrid opiate receptors induced by $N$-ethylmaleimide. Mol. Pharmacol. 20: 255-262.

Lord, J. A., A. A. Waterfield, J. Hughes, and H. W. Kosterlitz (1977) Endogenous opioid peptides: Multiple agonists and receptors. Nature 267: 495-499.

Lowry, O. H., N. J. Rosebrough, A. L. Farr, and R. J. Randall (1951) Protein measurement with the folin phenol reagent. J. Biol. Chem. 193: 265-275.

Marzullo, G., and A. J. Friedhoff (1977) An inhibitor of opiate receptor binding from human erythrocytes identified as a glutathione-copper complex. Life Sci. 21: 1559-1568.

Marzullo, G., and B. Hine (1980) Opiate receptor function may be modulated through an oxidation-reduction mechanism. Science 208: 1171-1173.

Pasternak, G. W., H. A. Wilson, and S. H. Snyder (1975) Differential effects of protein modifying reagents on receptor binding of opiate agonists and antagonists. Mol. Pharmacol. 11: $340-351$.

Pert, C. B., and S. H. Snyder (1974) Opiate receptor binding of agonists and antagonists affected differentially by sodium. Mol. Pharmacol. 10: 868-879.

Ross, E. M., T. Haga, A. C. Howlett, J. Schwarzmeir, L. S. Schleifer, and A. G. Gilman (1978) Hormone-sensitive adenylate cyclase: Resolution and reconstitution of some components necessary for regulation of the enzyme. Adv. Cyclic Nucleotide Res. 9: 56-67.

Sharma, S. K., M. Nirenberg, and W. A. Klee (1975) Morphine receptors as regulators of adenylate cyclase activity. Proc. Natl. Acad. Sci. U. S. A. 72: 590-594.

Simon, E. J., and J. Groth (1975) Kinetics of opiate receptor inactivation by sulfhydryl reagents: Evidence for conformational change in presence of sodium ions. Proc. Natl. Acad. Sci. U. S. A. 72: 2404-2407.

Simon, E. J., J. M. Hiller, and I. Edelman (1973) Stereospecific binding to the potent narcotic analgesic $\left[{ }^{3} \mathrm{H}\right]$ etorphine to ratbrain homogenate. Proc. Natl. Acad. Sci. U. S. A. 70: 1947-1949. 
Simon, E. J., J. M. Hiller, I. Edelman, J. Groth, and K. D. Stahl (1975) Opiate receptors and their interactions with agonists and antagonists. Iife Sci. 16: 1795-1800.

Spiehler, V., A. S. Fairhurst, and L. O. Randall (1978) The interaction of phenoxybenzamine with the mouse brain opiate receptor. Mol. Pharmacol. 14: 587-595.

Stadel, J. M., and R. J. Lefkowitz (1979) Multiple reactive sulfhydryl groups modulate the function of adenylate cyclase coupled beta-adrenergic receptors. Mol. Pharmacol. 16: 709-718.

Wilson, H. A., G. W. Pasternak, and S. H. Snyder (1975) Differentiation of opiate agonist and antagonist receptor binding by protein modifying reagents. Nature 253: 448-450.

Zukin, R. S., S. Walczak, and M. H. Makman (1980) GTP modulation of opiate receptors in regions of rat brain and possible mechanism of GTP action. Brain Res. 186: 238-244. 